\title{
Consumer perceptions of $B$ corporations, purpose-driven brands and cause-related marketing campaigns: knowledge, acceptance and appreciation at the time of purchase
}

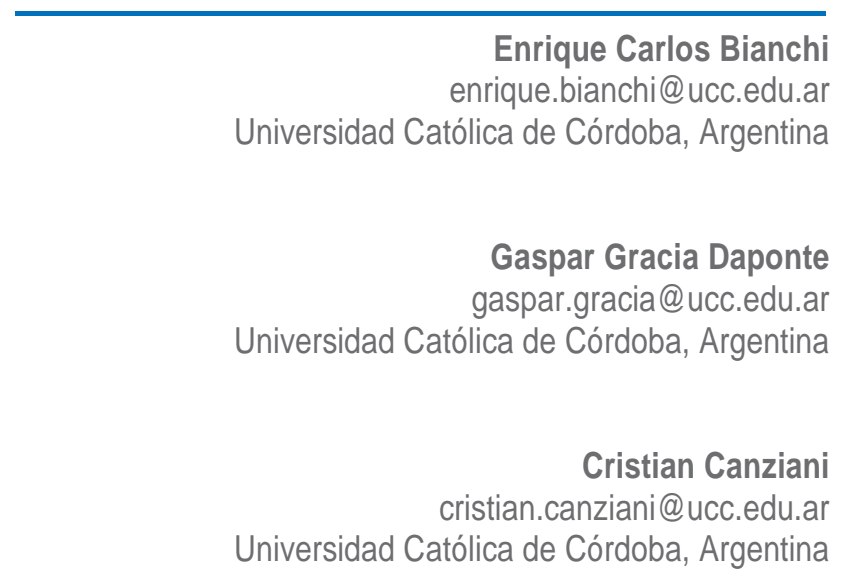


Bianchi, E.C., Daponte, G.G. and Canziani, C. (2020) Consumer perceptions of B corporations, purpose-driven brands and cause-related marketing campaigns: Knowledge, acceptance and appreciation at the time of purchase, Vol.12(1): 3-21

\begin{abstract}
For the Argentine case, studies that identify increasing implementation of three major CSR triple-impact strategies-B corporations, purpose-driven brands and marketing, and cause-related marketing-focus predominantly on supply.

The present study seeks to identify consumer perceptions of these three triple-impact strategies in terms of recognition, knowledge, appreciation, and prioritization at the time of the purchase in the Argentine market.

A quantitative investigation was carried out, based on a nationwide panel of 400 citizens. The results show that a majority of participants do not recognize the concepts of purposedriven brands or the concept of B corporations. Many express difficulties in identifying such initiatives due to disinterest, ignorance, and/or lack of availability/exposure. In addition, there were non-significant differences in terms of generations, socioeconomic level, and sex. On the other hand, almost half of the panel has some familiarity with cause-related marketing campaigns, given the association with NGOs to which participating companies may donate or fund-raise. The results, particularly the limited overall recognition of these concepts, has management implications in a context of recession and spending restrictions.
\end{abstract}

\title{
Resumen
}

Para el caso argentino, los estudios que identifican la creciente implementación de tres importantes estrategias de RSE de triple impacto - empresas B, marcas y marketing orientados a propósitos, y marketing vinculado a una causa - se enfocan principalmente en la oferta.

El presente estudio busca identificar las percepciones del consumidor sobre estas tres estrategias de triple impacto en términos de reconocimiento, conocimiento, apreciación, y priorización al momento de la compra en el mercado argentino.

Se realizó una investigación cualitativa, basada en un panel nacional de 400 ciudadanos. Los resultados muestran que la mayoría de los participantes no reconocen los conceptos de marcas orientadas a propósitos o el concepto de empresas B. Muchos muestran dificultades en identificar tales iniciativas debido a la falta de interés, ignorancia y/o la falta de disponibilidad/exposición. Además, hubo diferencias no significativas en términos de generaciones, nivel socioeconómico, y sexo. Por otro lado, casi la mitad del panel tiene cierta familiaridad con campañas de marketing vinculadas a causas, dada la asociación con ONGs a las que las empresas participantes pueden donar o recaudar fondos. Los resultados, particularmente el reconocimiento general limitado de estos conceptos, tienen implicancias en la gestión en un contexto de recesión y restricciones de gasto.

\section{Keywords:}

Purpose-driven marketing, B corporations, cause-related marketing, knowledge, consumer value. 
Bianchi, E.C., Daponte, G.G. and Canziani, C. (2020) Consumer perceptions of B corporations, purpose-driven brands and cause-related marketing campaigns: Knowledge, acceptance and appreciation at the time of purchase, Vol.12(1): 3-21

\section{Introduction}

Among studies that identify growth in the triple-impact initiatives B corporations, purpose-driven brands and marketing, and cause-related marketing, as part of corporate social responsibility (CSR) initiatives in Argentina, there is a predominant focus on supply.

These three innovative concepts, each with different roots but with similar ends, are important because they are part of an attempt to address significant problematics facing contemporary society. Thus, there is an interest in studying these concepts in order determine to what extent they add economic, social, and environmental value.

The purpose of the present qualitative study is to identify consumer perceptions of the three types of initiative in terms of recognition, knowledge, appreciation, and prioritization at the time of purchase, with particular emphasis on those who seek to practice responsible and sustainable consumption.

As well as this profile of responsible consumer, the study takes into account personal financial situation in the present context of social complexity and economic downturn.

The conclusions are in keeping with those of several previous studies: as public awareness of ethical, economic, social, and environmental problems increases, so too does the recognition and adoption of these new purchasing and consumption options.

As such, this study aims to contribute to the recent literature on hybrid companies, proposals for a new economy, and new social responsibility and sustainability paradigms. The rest of the paper is structured as follows. The second section reviews the literature on the three concepts studied: B corporations; cause-related marketing; and purpose-driven brands. The third section describes the research methodology, the design of the data-gathering instruments, and the measurement scales. The fourth section presents the results obtained and compares them with the main hypotheses. The final section sets out the conclusions, limitations, and lines of research arising from this study.

\section{Literature review}

\section{Companies and their responsibility to the community}

Hybrid companies are emerging as part of new proposals for business organizations within a new economy, geared toward not only profit motives but also social ends such as organizational culture, the environment, and social and community context.

Figure 1 displays the conceptual model whereby traditional capitalist companies and public institutions pursue new responses to production and employment problems, creating social value for the communities in which they operate. This is channeled through a range of organizational initiatives, programs, projects, and structures. 
Bianchi, E.C., Daponte, G.G. and Canziani, C. (2020) Consumer perceptions of B corporations, purpose-driven brands and cause-related marketing campaigns: Knowledge, acceptance and appreciation at the time of purchase, Vol.12(1): 3-21

Today, companies display greater awareness and responsibility regarding their social roles. CSR initiatives are on the increase and brand owners are committing to proposals whose intended benefits go beyond the operational, emotive, and self-expressive in pursuit of an overarching purpose whereby they can connect with and promote social causes. This is where purpose-driven branding and marketing come in.

Moreover, public agencies are creating space for the development of a civil society organized around the formulation of solutions to various problematics, in a framework of freedom and initiative. This involves civil organizations that aim to compliment and overcome the lack of response to precariousness in the spheres of healthcare, education, and culture, among others. When it comes to the attainment of their goals, the organizations partner with private firms to consolidate their resources and social positioning; it is in this context that cause-related marketing campaigns emerge.

Finally, beyond the transformation of companies, civil organizations, and the state in terms of goals, objectives, and targets, some companies adopt the triple-impact ethos from the point of their conception: the so-called B corporations.

\section{B corporations}

B corporations have been thus identified since 2007 in the United states and since 2012 in Latin America, where Chile is the country with the highest number of companies with this certification (Tapia \& Zegers, 2014). They are certified by an external agency--B Lab, in the United States--and define themselves as a new type of enterprise that utilizes market power to solve social and/or environmental problems (Cea et al., 2016).

According to the most recent Reporte del Índice de Triple Impacto (Empresa B + Deloitte, 2019) for Argentina, there are 2,172 B corporations in the country (1,950 medium-sized and large, and 222 micro and small). This report does not rank brand positioning, nor does it identify market-leading companies in terms of sustainability practices; rather, it presents information based on the voluntary participation of the companies, which report their economic, social, and environmental impact by way of the B Impact Assessment. As such, it does not involve a corporate review or an auditing process.

B corporations are a hybrid between organizations with social purposes and socially responsible firms (Masson, 2012)—which, traditionally, are either for-profit or not-forprofit (Campos, 2014) -and pertain to an emerging convergence process in which various actors are looking to use market instruments to create public goods (Abramovay et al., 2013). These companies are borne of the conviction of executives to operate differently in traditional business environments, and are sometimes supported by product certifications (organic, fair trade) or management certification (FSC sustainable forestry). 
Figure 1. Conceptual model: CSR (purpose-driven brands), B corporations, and causerelated marketing.

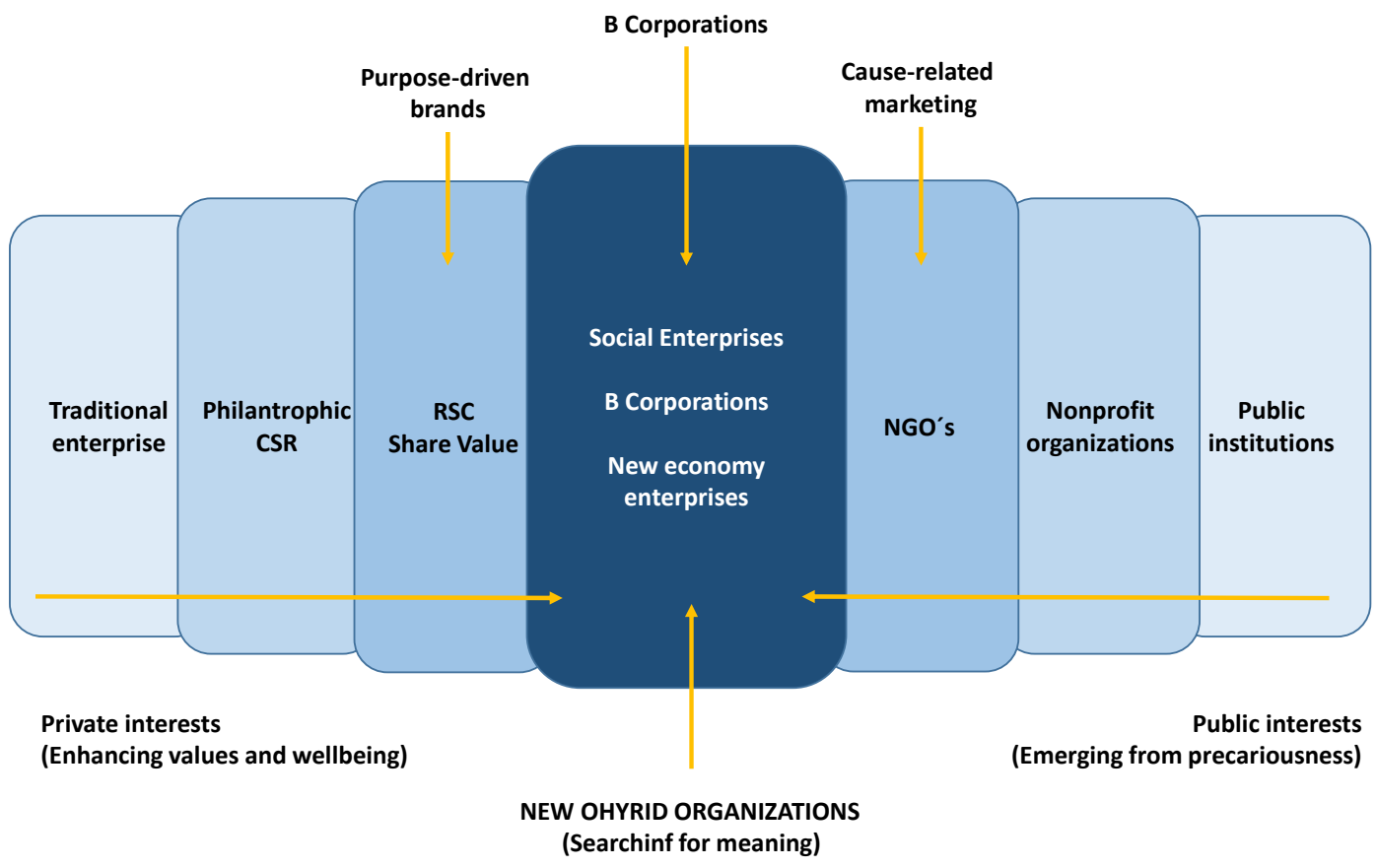

Source: Compiled by authors based on Haigh and Hoffman (2012) and Hoffman and Badiane (2012), both quoted in Correa et al. (2019).

They are targeted at the new and growing profile of consumers who place a high value on healthy living, social justice, respect for the environment, and the sustainability of the products and services they buy. These consumers invest in responsible companies, support green policies, and look for work that suits their lifestyle (Haigh \& Hoffman, 2012).

B corporations place their purpose at the heart of the business model, based on the principles of transparency, respect for workers, environmental protection, and the promotion of a community of companies with a common identity. Certified B corporations are for-profit, and legally bound to make a positive impact on their employees, communities, and the environment. The founders of B Lab, Jay Coen Gilbert, Bart Houlahan, and Andrew Kassoy, argue that a fundamental feature of B corporations is that the purpose of creating a positive impact is inherent to the business model--part of their DNA--and not a secondary consideration (Correa, 2019).

Gatica, Miranda y Koljatic propose the main attributes of hybrid, or "fourth" sector", organizations. They: a) incorporate social and/or environmental objectives as part of their organizational purpose; b) reconcile economic objectives and market mechanisms with their social and/or environmental objectives; c) hold themselves accountable to their stakeholders as well as owners and shareholders; d) distribute profits in a way that does not adversely affect their stakeholders, or the attainment of their mission; and e) commit to report their economic, social, and environmental results under the most rigorous standards of transparency (Gatica, Miranda, \& Koljatic, 2013). 
Bianchi, E.C., Daponte, G.G. and Canziani, C. (2020) Consumer perceptions of B corporations, purpose-driven brands and cause-related marketing campaigns: Knowledge, acceptance and appreciation at the time of purchase, Vol.12(1): 3-21

B corporations are intended to make an impact in four areas-governance, environment, employees, and the community - to which a fifth, consumers, has recently been added (Sharma et al., 2018).

The collaborative business model allows companies to create and maximize their income through experiences co-created with local communities. This approach has proven effective in vulnerable territories by promoting trust, reciprocity, and partnership between communities and local enterprises, as well as with larger-scale entrepreneurs (Zebryte \& Jorquera, 2017).

\section{Purpose-driven brands}

Consumers in increasing numbers are calling for brands that are more authentic. This demand for authenticity constitutes a persistent and fundamental undercurrent in the life of the consumer (Beverland \& Farrelly, 2010; Grayson \& Martinec, 2004). For Brown et al. (2003), "the search for authenticity is one of the cornerstones of contemporary marketing" (p. 21). In essence, what individuals seek in brands is purpose, and this desire is becoming more intense among newer generations.

In recent years, consumers have opted increasingly for specific purpose-driven brands that demonstrate values and intentions beyond the simple pursuit of profit (Schaeffer, 2019; KPMG, 2018).

As a result, purpose-drive brands enjoy more pronounced growth (Hsu, 2017) and a deeper connection with consumers. Today, companies have the means of shaping culture and society (Biraghi et al., 2020), and so being a purpose-driven business is not an option but a commitment to the change that society wishes to see. Experience is showing that a purpose is required to achieve a lasting competitive advantage, acquire talent, and secure business growth (Kantar, 2020; Hochman et al., 2012)

In turn, through purpose-driven marketing, the brand connects with its audience by way of causes in which both believe. Brand messaging is aligned with the beliefs of the consumer, who in turn believes in and supports the brand. Purpose-driven marketing must be seen as a long-term strategy.

According to Miltenburg (2017), a brand that provides a purpose serves as a compass for giving direction and a filter for making decisions. The brand is to be chosen. It cannot be something to everyone or it will end up being nothing to anyone. A strong brand aids decision-making about new opportunities and creates a solid corporate culture in which values are shared and actions are in alignment. In the current consumer environment, this desire for authenticity can even prevail over normal purchase considerations such as product price and availability. Authentic products and experiences let consumers momentarily escape the world of exploitative commercial consumption and, if these products are sufficiently compelling in terms of brand values and personality, they can connect with individuals on a deeper level and even become embedded in the culture (Gundlach \& Neville, 2012). 
Bianchi, E.C., Daponte, G.G. and Canziani, C. (2020) Consumer perceptions of B corporations, purpose-driven brands and cause-related marketing campaigns: Knowledge, acceptance and appreciation at the time of purchase, Vol.12(1): 3-21

\section{Cause-related marketing}

Cause-related marketing is defined as the set of "activities carried out by for-profit business organizations in support of social causes. It is not exactly social marketing. The philanthropic actions performed are just one means of achieving the ultimate aim of increasing sales and profits" (Santesmasses, 1999, p. 1004; translation ours).

Cause-related marketing and purpose-driven marketing may appear synonymous, but the former tends to be shorter term and oriented toward specific campaigns. That is, a brand will select a charitable cause to promote by way of a time-limited campaign (one month, for instance). The brand can associate itself with the charitable organization that it promotes, and collect or donate income through the business.

Thus, cause-related marketing represents a kind of joint initiative between a company and an NGO. But collaboration agreements can take other forms as well, such as corporate philanthropy, licenses, sponsorship, and joint ventures (Wymer \& Samu 2003).

Pérez et al. (2014) argue that interactions between companies and NGOs generate relationship models that combine imitation, cooperation, and competition. In this new context, alliances can create different types of value for the NGO (Austin \& Seitanidi 2012b), including not only traditional "associative" value (greater visibility, credibility, public recognition of the social cause) or "transfer" value (financial support, donations in kind, volunteering, etc.), but also other forms on a larger scale, such as "interaction" value (learning opportunities, development of unique capabilities, network access, etc.) or "synergy" value (innovation, shared leadership, etc.).

In light of the foregoing, the following hypotheses can be proposed:

$\mathrm{H}_{1}$ : B corporations and purpose-driven brands are more-recent concepts, and are thus less recognized than cause-related marketing.

$\mathrm{H}_{2}$ : Purpose-driven brands, $\mathrm{B}$ corporations, and cause-related marketing campaigns are distinguishing attributes, valued by consumers in the lead-up to purchase.

$\mathrm{H}_{3}$ : The greater a consumer's awareness of responsible and sustainable consumption, the more they will recognize these initiatives and appreciate them as attributes prior to purchase.

$\mathrm{H}_{4}$ : The better the personal financial situation of a consumer, the more they will recognize these initiatives and appreciate them as attributes prior to purchase. 
Bianchi, E.C., Daponte, G.G. and Canziani, C. (2020) Consumer perceptions of B corporations, purpose-driven brands and cause-related marketing campaigns: Knowledge, acceptance and appreciation at the time of purchase, Vol.12(1): 3-21

\section{Methodology of study}

This section presents the methodology employed; that is, the research design, the datacollection instrument, the measurement scales, and the fieldwork conducted.

\section{Research design}

This is a quantitative study; the universe is composed of individuals aged between 16 and 65 years who inhabit the four most populous cities of Argentina: Buenos Aires Metropolitan Area, Córdoba, Rosario, and Mendoza, which house around 43\% of the population, or 45.3 million people (National Institute of Statistics and Censuses, 2010).

A non-probabilistic sampling procedure was designed with quotas of gender, age, and cities of origin, and applied, through a citizens' panel and questionnaire, by the company Oh! Panel in November 2019. There was a total of 400 valid cases, after elimination of incomplete responses, late submissions, or those atypical responses. The resulting sample profile is presented below:

Table 1. Sample profile

\begin{tabular}{llcc}
\hline & Category & Frequency & $\%$ \\
\hline \multirow{3}{*}{ Sex } & Female & 216 & $54 \%$ \\
& Male & 184 & $46 \%$ \\
Age & Between 16 and 34 & 128 & $32 \%$ \\
& Between 35 and 49 & 140 & $35 \%$ \\
& Between 50 and 65 & 132 & $33 \%$ \\
& Buenos Aires Metropolitan Area & 160 & $40 \%$ \\
& Córdoba & 80 & $20 \%$ \\
& Rosario & 80 & $20 \%$ \\
& Mendoza & 80 & $20 \%$ \\
\hline
\end{tabular}

Source: Own elaboration

The participants answered questions about their purchasing and consumption habits; their criteria and motives for purchasing or not purchasing products pertaining to purpose-driven brands, B corporations, or cause-related marketing campaigns; the value they place on these attributes in comparison with more conventional models; their 
Bianchi, E.C., Daponte, G.G. and Canziani, C. (2020) Consumer perceptions of B corporations, purpose-driven brands and cause-related marketing campaigns: Knowledge, acceptance and appreciation at the time of purchase, Vol.12(1): 3-21

spontaneous recognition of specific brands; their loyalty toward these brands; and their likelihood to recommend them to others.

The questionnaire contains four sections containing questions on participants': a) perceptions about the evolution of the national context and their personal situation; b) purchase habits and changes thereto; c) awareness and perception of purpose-driven brands and cause-related marketing, and how visible and important they consider them to be; and d) knowledge about the profile of responsible and sustainable consumers.

\section{Variables and measurement scales}

The variables and the scales utilized, and their sources, are presented below.

Context evaluation: The scales for measuring respondents' perceptions about their current and future financial situation were taken from the Latinobarómetro.

Consumer habits. First, participants were asked about changes in their consumption habits, via two dichotomous questions: "Do you think that you and/or your family have changed your purchasing habits over the last year?"; "Have you and/or your family cut back on your spending over the last year?" Second, they were asked about their consumer behavior, by way of five Likert-scale questions: "I look for offers and/or promotions," "I have reduced my expenses overall," "I have cut out unnecessary expenses and only consume what is immediately necessary," "I buy more second-tier brands," "I compare prices more carefully," "I try to buy in installments to beat inflation."

Concept recognition. through the following questions, the participants were asked which of the following statements best expressed their level of awareness of the concepts of purpose-driven brands, B corporations, and cause-related marketing: "I have never heard of it before;" "I knew it existed but it wasn't a consideration;" "I knew about it and consider it appealing; and "don't know/did not answer." The conceptual definitions evaluated were as follows:

o "Purpose-driven marketing: a way of connecting a brand with the needs and interests of its consumers, generally in relation to social, environmental, or political issues that contribute to improving life and even to making a better world. In this way, the purpose-driven brand seeks to create a deeper connection with its customers through a common goal that transcends the transaction."

o " $B$ corporations: those that seek to reconcile economic development, social development, and environmental protection. B corporations are a new type of enterprise that seek to utilize market forces to address the social and/or environmental problems of the communities where they operate, pursuing the dual mission of generating reasonable profits for their shareholders and creating, through their main activity, social benefits. To legally protect this dual mission against possible changes of direction, companies incorporate a commitment to social and/or environmental impact in their by-laws." 
Bianchi, E.C., Daponte, G.G. and Canziani, C. (2020) Consumer perceptions of B corporations, purpose-driven brands and cause-related marketing campaigns: Knowledge, acceptance and appreciation at the time of purchase, Vol.12(1): 3-21

- "Cause-related marketing is a CSR initiative that entails an agreement between a company and an NGO to collaborate on a social cause and achieve, in this way, mutual benefit. A company's commitment is centered on contributing, economically or in kind, to a cause based on sales or product usage (donation will therefore depend on consumer behavior). An example of a campaign was that between the company Villavicencio and the Banco de Bosques Foundation, with the slogan "leave your footprint: with each bottle you help to regenerate a 2 of rainforest in Misiones."

Purpose-driven brands were measured across the following dimensions:

o Purchase behavior and motives: the participants were asked about their purchase behavior toward such brands, based on a six-point scale: "I don't buy because they doesn't interest me;" "I don't buy because I'm not familiar with them or don't recognize them;" "I don't buy them because I can't find availability;" "I buy them routinely;" I will buy them in the future."

o Perception: A three-item Likert scale was used: "To buy purpose-driven brands is to set a good example for others;" "This purpose-driven brand is just as effective as other products;" "This purpose-driven brand is good value for money."

o Loyalty: A three-item Likert scale was used: "Purpose-driven brands are for me, they are always my first choice;" "If I can't find that purpose-driven brand, I won't buy another one;" "I consider myself loyal to that purpose-driven brand."

o Willingness to pay more: Three-item Likert scale: "I buy a purpose-driven brand, even if I have to pay a higher price", "I'm willing to pay more for a purpose-driven brand;" "If other brands reduced their price by 10\%, I would still buy that purposedriven brand."

o Recommendation: Two-item Likert scale: "I usually suggest that my friends use purpose-driven brands;" "I recommend that my friends buy purpose-driven brands."

In turn, B corporations and cause-related marketing were measured across the following dimensions:

o Importance of the attribute before buying: the participants were asked, through two questions, how frequently they take into account, before purchase, the impact that a B corporation brand and/or a cause-related marketing campaign has on both environmental and human well-being. The possible answers were: "Always;" "Sometimes;" and "Never/l don't consider it."

o Intention: Participants were asked whether, when buying a product or service, they would choose a B corporation (with a better social or environmental performance) and/or a company that has employed a cause-related marketing campaign (support an NGO), even though these options were more expensive. This involved two questions, with the following possible answers: "Yes, only if it is a little more expensive (around 10\%);" "Yes, even if it is much more expensive (from 11 to 25\% more)", "No, I would only buy it if the price were the same." 
Cause-related marketing campaigns were measured across the following dimensions:

o Attitude toward cause-related marketing: A four-item Likert scale was used: "I like the idea of buying products whereby part of the profits are donated to a social cause or an NGO;" "If a company is donating part of its profits to an NGO or a social cause, I will be more likely to buy their products;" "companies that announce that they are donating part of their profits to an NGO or a social cause are good corporate citizens;" "I am willing to pay more if the manufacturer is donating part of its profits to a social cause or an NGO."

o Attitude to NGOs: A five-item Likert scale was used: "I believe that the work of NGOs is necessary to help others;" "I think NGOs are concerned about raising money, but we don't know what they do with it;" "I think there are other more effective ways to help than NGOs;" "I think we all need to contribute in some way with an NGO;" I think that NGOs worry too much about marketing and advertising."

o Intention to donate to NGOs: A two-item Likert scale was used: "Next time I'll certainly support a campaign run by an NGO;" "It's very likely that I'll donate to an NGO in the future:" "I'll definitely donate to the cause of an NGO."

\section{- Responsible and sustainable consumption:}

o Awareness: A five-item Likert scale was used: "I try to avoid buying products from companies that are not ethical or socially responsible;" "If two products are of the same price and quality, l'll choose the one from the socially responsible company;" "I'd be willing to pay a little more for ethical and socially responsible products;" "I consider the ethical reputation of the company before buying;" and "When buying I take into account the social actions in support of NGOs that the company/brand takes."

o Action: Five-item Likert scale: "At home, I turn off lights and electrical appliances that are not being used to save energy;" "I choose products with recyclable, ecological and low-environmental-impact packaging," "I avoid wasting water (when I shower, wash dishes, wash my car, or water the plants); "I help different NGOs that ask for donations and contributions (money, clothes, technology, paper, lids, etc.);" "I separate waste (paper-plastic-glass-organic) at home"

Table 2 provides an overview of the variables and scales used, with the corresponding initial reliability indicator of reliability. 
Table 2. Overview of variables and measurement scales

\section{Scales}

Purpose-driven brands

Recognition

Purchase attribute

Perception

Loyalty/fidelity

Willingness to pay more

Recommendation

B corporations

Recognition

Willingness to pay more

Purchase attribute

\section{Cause-related marketing}

Recognition

Attitude marketing

Attitude toward NGOs

Intention to donate/participate in a 3 campaign

Responsible and sustainable consumption

\begin{tabular}{lll} 
RSC awareness & 5 & 0.876 \\
RSC actions & 5 & 0.769 \\
\hline
\end{tabular}

Cronbach's alpha

0.868

0.922

0.922

0.969

1

1

1

1

4

0.878

5

0.794

0.935

Source: Own elaboration

\section{Results}

\section{Consumer perception}

The first relevant indicator in the study is the level of recognition of the concepts--causerelated marketing, $\mathrm{B}$ corporations businesses, purpose-driven brands-- by the universe of consumers. Here, it was found that $55 \%$ of the population recognized at least one of the three concepts associated with the new generation of hybrid enterprises. 
Bianchi, E.C., Daponte, G.G. and Canziani, C. (2020) Consumer perceptions of B corporations, purpose-driven brands and cause-related marketing campaigns: Knowledge, acceptance and appreciation at the time of purchase, Vol.12(1): 3-21

Almost half of the population recognized cause-related marketing campaigns (46\%) and B corporations (44\%), while the more recently developed concept of purpose-driven brands was only recognized by one out of every four consumers (25\%).

The second indicator is the importance that consumers who recognize these concepts attach to them as an evaluation criterion for deciding to purchase. This indicator is one that two out of three consumers who identify both B corporations and cause-related marketing campaigns, and two out of five of those who recognize purpose-driven brands, apply sporadically ("sometimes"). This shows that the concepts are not given all that much consideration prior to purchase; that is, they are not considered determining attributes.

Table 3. Recognition and appreciation of attribute before purchase

\begin{tabular}{|c|c|c|c|}
\hline & $\begin{array}{l}\text { Purpose- } \\
\text { driven } \\
\text { brands }\end{array}$ & $\begin{array}{l}\text { B } \\
\text { corporation } \\
\text { S }\end{array}$ & $\begin{array}{l}\text { Cause- } \\
\text { related } \\
\text { marketing }\end{array}$ \\
\hline \multicolumn{4}{|l|}{ Recognition of concept } \\
\hline Assisted recognition & $24.8 \%$ & $44.3 \%$ & $46.3 \%$ \\
\hline \multicolumn{4}{|c|}{ Appreciation of attribute before purchase by those who recognize the concept } \\
\hline Habitual purchase (always) & $8.1 \%$ & $10.3 \%$ & $13.5 \%$ \\
\hline Occasional purchase (at times) & $22.2 \%$ & $68.4 \%$ & $66.5 \%$ \\
\hline $\begin{array}{l}\begin{array}{l}\text { Future } \\
\text { (never) }\end{array} \\
\text { purchase/not purchased }\end{array}$ & $69.7 \%$ & $21.4 \%$ & $20.0 \%$ \\
\hline
\end{tabular}

Source: Own elaboration

Next, the perception/attitude of consumers regarding these concepts, in terms such as degree of loyalty and likelihood of recommending to others, is studied. The results show that both cause-related marketing and purpose-driven brands are well-received--that is, they evoke a positive attitude--with mean values of 3.51 and 3.39 (see Table 4). Purposedriven brands elicit a favorable attitude that prompts consumers to recommend them to others, to a greater extent than the loyalty they show toward them and willingness to pay more. Meanwhile, cause-related marketing campaigns tend to evoke a positive attitude toward the NGOs that participate in them, as well as an intention to donate or participate in a campaign of this type (average values of 3.5 and 3.45, respectively). 
Bianchi, E.C., Daponte, G.G. and Canziani, C. (2020) Consumer perceptions of B corporations, purpose-driven brands and cause-related marketing campaigns: Knowledge, acceptance and appreciation at the time of purchase, Vol.12(1): 3-21

Table 4. Main indicators in the consumer perception index

\begin{tabular}{|c|c|c|c|}
\hline Scales & $\mathbf{n}$ & Average & $\begin{array}{l}\text { Standard } \\
\text { deviation }\end{array}$ \\
\hline \multicolumn{4}{|l|}{ Purpose-driven brands } \\
\hline Perception & 99 & 3.39 & 0.82 \\
\hline Loyalty/fidelity & 99 & 2.74 & 1.19 \\
\hline Recommendation & 99 & 3.29 & 0.94 \\
\hline Willingness to pay more & 99 & 2.73 & 1.23 \\
\hline \multicolumn{4}{|l|}{ Cause-related marketing } \\
\hline $\begin{array}{l}\text { Attitude toward cause-related } \\
\text { marketing }\end{array}$ & 185 & 3.51 & 0.85 \\
\hline Attitude toward NGOs & 185 & 3.45 & 0.68 \\
\hline $\begin{array}{l}\text { Intention to donate/participate in a } \\
\text { campaign }\end{array}$ & 185 & 3.35 & 0.92 \\
\hline
\end{tabular}

Scale: 1 (totally agree) to 5 (totally disagree).

Source: Own elaboration

\section{Perception of responsible consumers}

It is worth identifying whether consumers with a profile of responsible and sustainable consumption appraise these initiatives in a different way than those consumers who do not have such a profile. To this end, the procedure proposed by Homburg and Giering (2001) and Wangenheim (2003) is employed; this entails forming two groups based on the median of the variable as a cut-off value, discarding those cases in which the median is contained in the interval between the median minus the standard deviation ("low") and the median plus the standard deviation ("high"'"). As a result, 53 cases of high awareness of RSC and 28 cases of low awareness of RSC were identified.

Figure 2. Responsible and sustainable consumer: Recognition (aided awareness)

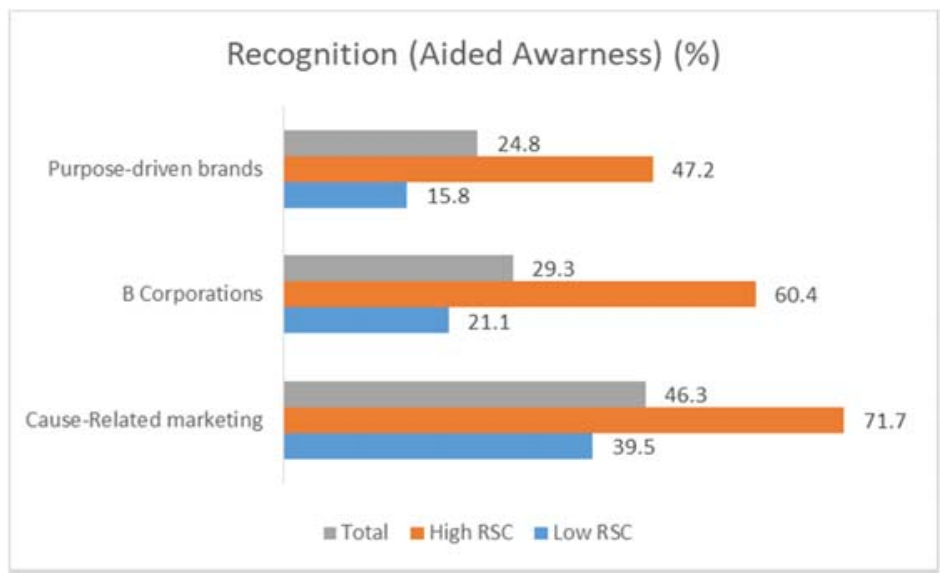

Source: Own elaboration 
It was found that individuals with a high level of awareness of responsible and sustainable consumption ("high RSC awareness") tend to recognize more purposedriven brands, B corporations, and cause-related marketing campaigns (47\%, 60\%, and $71 \%$, respectively) than consumers with a low level of awareness of responsible and sustainable consumption ("low RSC awareness"), resulting in significant differences in statistical terms $(F(1.89)=10.31, p<0.005 ; F(1.89)=16.03, p<0.005 ; F(1.89)=10.62$, $\mathrm{p}<0.005$ ) (see Figure 2).

Figure 3. Responsible and sustainable consumer: Perception, recommendation, and attitude
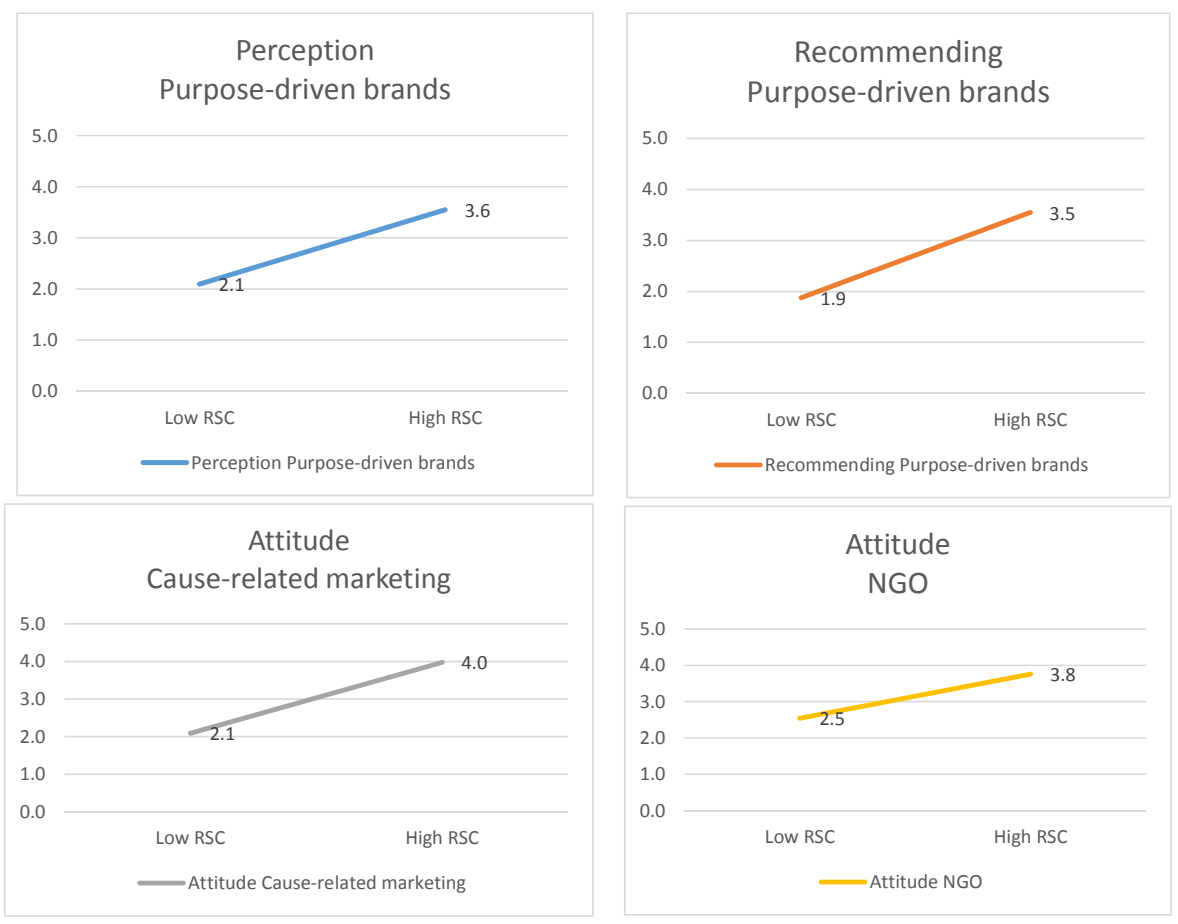

Source: Own elaboration

In this case, the results confirm the hypothesis that those with a high level of awareness of responsible and sustainable consumption ("high RSC awareness") have a greater perception of brands with purpose, a stronger likelihood of recommending them, and a better attitude toward cause-related marketing and to NGOs than consumers with limited awareness of responsible and sustainable consumption ("low RSC awareness"). The differences obtained are significant in statistical terms $(F(1.76)=39,31, p<0.001$; $F(1.77)=45.28 p<0.001 ; F(1.84)=87.55, p<0.001 ; F(1.82)=33.41 p<0.001$ ) (see Figure $3)$. 
Figure 4. Responsible and sustainable consumption, and personal situation: Perception, recommendation, and attitude

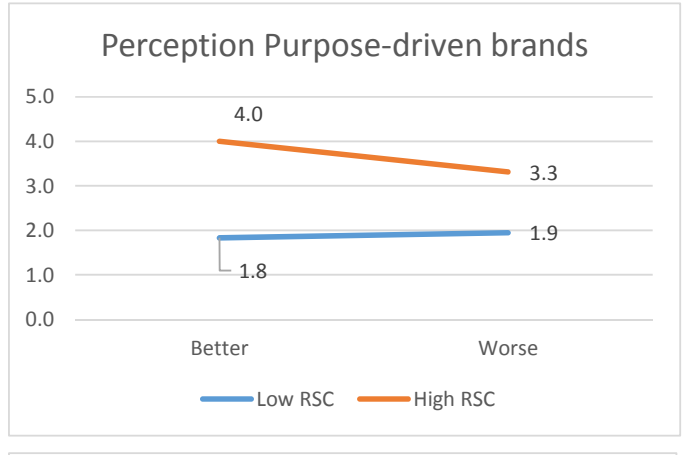

Attitude Cause-related marketing

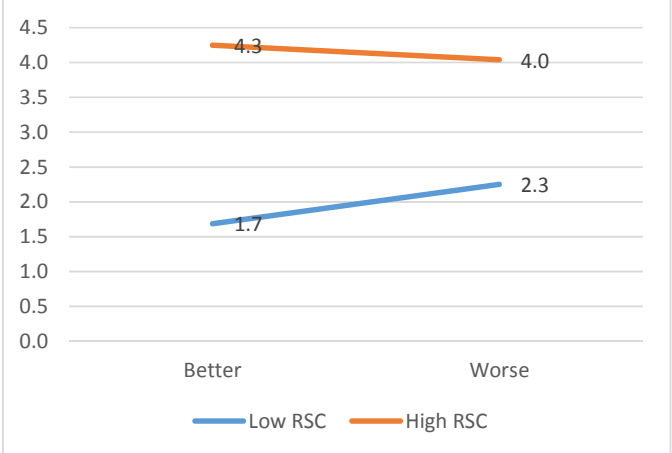

Source: Own elaboration

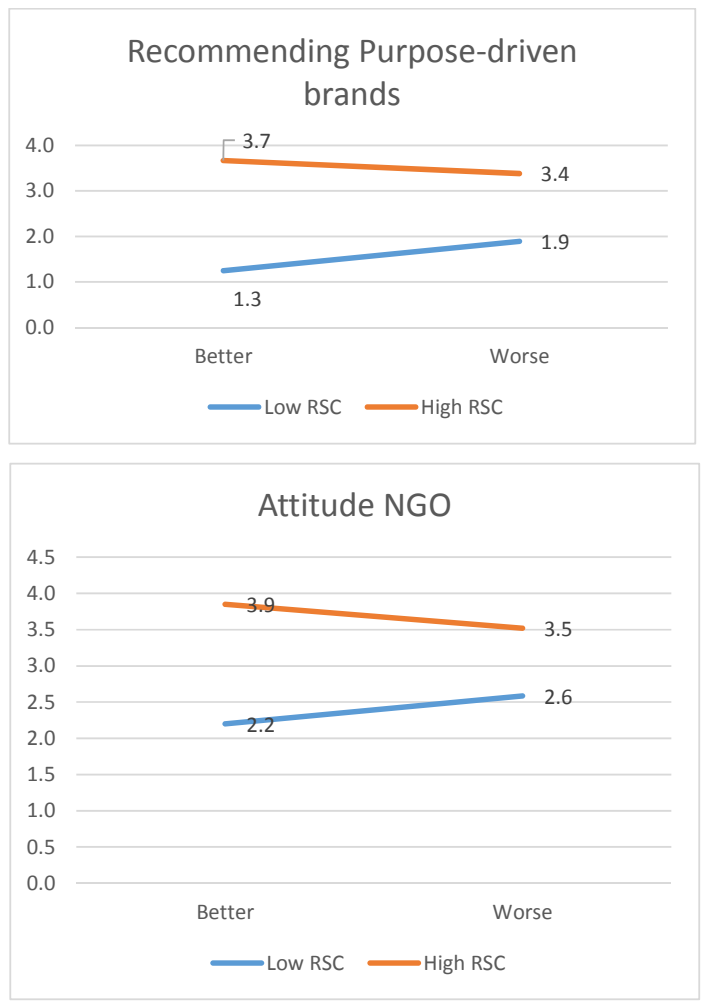

Finally, the results confirm the hypothesis that those enjoying a favorable personal financial situation ("better") have a better perception of purpose-driven brands, a higher likelihood of recommending them, and a more favorable attitude toward cause-related marketing and NGOs than consumers with a less favorable personal situation ("worse"). The differences obtained are not significant in statistical terms $(F(1.126)=0.437, p>0.01$; $F(1.135)=0.207, p>0.01 ; F(1.147)=0.552, p<0.01 ; F(1.137)=0.202, p>0.01$ ) (see Figure 4). As has been demonstrated, the variable that best explains differences in perception and attitude is awareness of RSC.

\section{Conclusions}

The aim of this study was to explore consumers' knowledge, acceptance, and appreciation, at the time of purchase, of B corporations, purpose-driven brands, and cause-related marketing campaigns. With regard to the research hypotheses, the results meant that:

Hypothesis $\mathrm{H}_{1}$ was confirmed. A little over half of the sample recognized at least one of the concepts; purpose-driven brands are the least known, by only one in four consumers. This is likely because these brands, along with B corporations, are relatively new concepts and are thus less known than cause-related marketing campaigns. 
In turn, Hypothesis $\mathrm{H}_{2}$ sought to ascertain whether these attributes are appreciated at the time of purchase. The results show that they are valued but not decisively so, and are taken into consideration only on some purchase occasions. This may be because the attributes do not respond to the functional needs, benefits, and priorities of consumers at the time of purchase, even if these consumers do regard the associated actions, characteristics, and intentions as laudable.

In turn, Hypothesis $\mathrm{H}_{3}$, that the higher the level of awareness of responsible and sustainable consumption, the greater the knowledge and appreciation of these concepts, was confirmed. More specifically, the results for consumers who exhibit high levels of awareness of RSC are almost double those for consumers who do not conform to this profile.

Finally, Hypothesis $\mathrm{H}_{4}$, was likewise proven: the personal financial situation of consumers has no influence on greater or lesser knowledge or appreciation of purpose-driven brands, B corporations, or cause-related marketing campaigns.

The results, conclusions, and limitations of this study pave the way for new lines of research. The reasons behind the limited appreciation of these offerings should be analyzed, as there are a multitude of possible factors that are not explored in the present study. Future studies could explore why they do not prove significant value propositions for consumers: for instance, whether cause-related marketing campaigns are seen as mere temporary and short-term strategies; whether B companies are perceived as being centered more on labor, environmental and community impact; whether purpose-driven brands work better in some market segments than in others; and whether these genuine purposes are not always attuned to the individual and social aspirations of consumers.

The main implications for companies and marketing managers is that these proposals resonate most with a specific section of society: individuals who seek to practice conscientious, responsible and sustainable consumption. One could affirm that the growth and social significance of purpose-driven brands, cause-related marketing campaigns, and B corporations are strongly linked to increasing consumer awareness and concern about the triple economic, social and environmental impacts. Thus, there is a vital need to foster new communities of interest that draw together consumers and citizens in a kind of movement for a new economy and a new social reality.

\section{References}

Abramovay, R., Correa, M. E., Gatica, S., \& Van Hoof, B. (2013). Nuevas empresas, nuevas economías: Las empresas $B$ en Sur América. Fondo Multilateral de Inversiones (FOMIN), miembro del Grupo del Banco Interamericano de Desarrollo. Fomin, BID, p. 165

Austin, J. E. \& Seitanidi, M. M. (2012). Collaborative value creation: A review of partnering between nonprofits and businesses. Part 2: Partnership processes and outcomes. Nonprofit and Voluntary Sector Quarterly, Vol. 41, No 6, p. 929-968. 
Bianchi, E.C., Daponte, G.G. and Canziani, C. (2020) Consumer perceptions of B corporations, purpose-driven brands and cause-related marketing campaigns: Knowledge, acceptance and appreciation at the time of purchase, Vol.12(1): 3-21

Biraghi, S., Gambetti, R. C., \& Quigley, S. (2020). Brand Purpose as a Cultural Entity Between Business and Society. In Social Entrepreneurship and Corporate Social Responsibility (pp. 401-422). Springer, Cham.

Brown, Stephen, Robert V. Kozinets, and John F. Sherry, Jr. (2003) Sell Me the Old, Old Story: Retromarketing Management and the Art of Brand Revival. In Journal of Customer Behavior, 2 (June), 85-98.

Campos, N. G. T. (2014). Aporte de la empresa privada en la construcción de valor social y propuesta de modelo de medición de impacto.

Cea-Valencia, J., Fernández-Robin, C., Santander-Astorga, P., Soto-Araya, D., \& Yáñez-Martínez, D. (2016). Comportamiento del consumidor chileno frente a productos de empresas B: Análisis de percepción de precio e intención de compra. $M B R, 9(2), 10-$ 16.

Correa, M. E. (2019) Sistema B y las empresas B en América Latina: Un movimiento social que cambia el sentido del éxito empresarial. CAF Banco de Desarrollo de América Latina, p. 212

Empresa B + Deloitte (2019) Índice de triple impacto. Mejores empresas, mejoran el país. $\quad$ Retrieved from: https://www2.deloitte.com/content/dam/Deloitte/ar/Documents/risk/reporte-indice-tripleimpacto-septiembre-2019.pdf

Gatica, E., Koljatic, M., \& Miranda, P. (2013). Hacia un marco de políticas públicas para el cuarto sector en Chile. AAVV. Propuestas para Chile, Concurso de políticas públicas/2013. Santiago de Chile: Pontificia Universidad Católica de Chile.

Groppa, O., \& Sluga, M. L. (2015). Empresas y bien común Caracterización de las empresas de Economía de Comunión y empresas B en la Argentina. Cultura Económica, 33(89), 8-24.

Gundlach, H. \& Neville, B. (2012) Authenticity: Further theoretical and practical development. Journal of Brand Management. Vol. 19, 484 - 499.

Gupta, V., \& Anand, S. Role of Cause marketing in Behavior Change: Critical Review of India's Most Celebrated Hygiene Campaigns.

Haigh, N., \& Hoffman, A. J. (2011). Hybrid organizations: the next chapter in sustainable business. Organizational dynamics, 41(2), 126-134.

Hochman, Kevin, and Kristi Maynor (2012). Integrating your brand purpose: How Procter \& Gamble's Secret deodorant increased market share and profit through its brand purpose. Journal of Brand Strategy 1.4, 327-332.

Hoffman, A. J., Badiane, K. K., \& Haigh, N. (2012). Hybrid organizations as agents of positive social change: Bridging the for-profit \& non-profit divide. Using a positive lens to explore social change and organizations: Building a theoretical and research foundation, 131.

Homburg, C., \& Giering, A. (2001). Personal characteristics as moderators of the relationship between customer satisfaction and loyalty-an empirical analysis. Psychology \& Marketing, 18(1), 43-66. 
Bianchi, E.C., Daponte, G.G. and Canziani, C. (2020) Consumer perceptions of B corporations, purpose-driven brands and cause-related marketing campaigns: Knowledge, acceptance and appreciation at the time of purchase, Vol.12(1): 3-21

Hsu, C. K. J. (2017). Selling products by selling brand purpose. Journal of Brand Strategy, 5(4), 373-394.

https://doi.org/10.1108/JJEBR-07-2017-0218

Kantar (2020) Purpose 2020 - Igniting Purpose Led Growth. Retrieved from: https://consulting.kantar.com/wp-content/uploads/2019/06/Purpose-2020-PDF-

Presentation.pdf

KPMG (2018) Tomorrow's experience, today. Global customer experience. Retrieved from: https://assets.kpmg/content/dam/kpmg/be/pdf/2018/06/tomorrows-experiencetoday-harnessing-a-customer-first-approach.pdf

Masson, T. (February 22, 2012). Learning from the B(enefit) Corp Assessment-Social Finance. Retrieved from http://socialfinance.ca/blog/post/learning- from-the-benefitcorp-assessment

Miltenburg, A. (2017) Brand the change: The branding guide for social entrepreneurs, disruptors, not-for-profits and corporate troublemakers.

National Institute of Statistics and Censuses (2010), "Censo, 2010", Buenos aires, available at: https://www.indec.gob.ar/indec/web/Nivel4-CensoNacional-3-6-Censo2010 (accessed 21 May 2020).

Pérez, S., Álvarez González, L., y Rey García, M. (2014). La innovación social como resultado de los acuerdos de cooperación empresa-organización no lucrativa, Aemark.

Santesmases Mestre, Miguel (1999): “Marketing. Conceptos y Estrategias", 4th edition. Editorial Pirámide. Madrid.

Schaeffer, M. (2019) Marketing rebellion: the most human company wins.

Sharma, G., Beveridge, A. J., \& Haigh, N. (2018). A configural framework of practice change for B corporations. In Journal of Business Venturing, 33(2), 207-224. https://doi.org/10.1016/j.jbusvent.2017.12.008

Tapia Velásquez, C., \& Zegers Vial, P. (2014). Análisis descriptivo de las empresas B en Chile.

Wangenheim, F. (2003). Situational characteristics as moderators of the satisfactionloyalty link: an investigation in a business-to-business context. Journal of Consumer Satisfaction, Dissatisfaction and Complaining Behavior, 16, 145.

Wymer, W.W. \& Samu, S. (2003). Dimensions of Business and Nonprofit Collaborative Relationships, Journal ofNonprofit \& Public Sector Marketing, Vol. 11, No.1, p. 3-22.

Zebryte, I., \& Jorquera, H. (2017). Chilean tourism sector "B Corporations": evidence of social entrepreneurship and innovation. International Journal of Entrepreneurial Behavior \& Research. 